\title{
Design, fabrication and evaluation of the cell micro-injector for improvement of the quality of subretinal space injection with minimum damage
}

\author{
Hamid Aboutaleb Kadkhodaeian ${ }^{1}$,Amir Salati ${ }^{2}$, Hamidreza Sameni ${ }^{3}$, Alireza Lashay ${ }^{4}$ \\ 1. Assistant Professor, Department of Anatomy, School of Medicine, Semnan University of Medical Sciences, Semnan, Iran., \\ (Corresponding Author), Tel: +9823-33654162, Email: Habootaleb92@ gmail.com. ORCID ID: 0000-0002-9736-9722 \\ 2. Assistant Professor, Department of Tissue Engineering and Applied Cell Sciences, Semnan University of Medical \\ Sciences, Semnan, Iran. ORCID ID: 0000-0002-6840-1527 \\ 3. Associate Professor, Nervous System Stem Cells Research Center, Semnan University of Medical Sciences, Semnan, Iran. \\ ORCID ID: 0000-0002-2669-6697 \\ 4. Professor, Farabi Eye Research Center, Tehran University of Medical Sciences, Tehran, Iran.
}

\begin{abstract}
Background and Aim: An accurate cell injection in therapeutic methods is one of the most important and challenging stages in animal and human cell therapy. The aim of this study was to design and fabricate a device for injecting stem cells into the subretinal space and the vitreous body in degenerative eye diseases.

Materials and Methods: In this study, the primary map of the device, metal molds and the appropriate tools for the machine were prepared. The pieces of the device were manufactured by a CNC machine and assembled together. In order to verify the device function we used immunohistochemistry (IHC) method and fluorescein was injected into the subretinal space of the rats. Tissue samples were examined by fluorescent microscope six and 24 hours after injection

Results: The results of IHC showed that six and 24 hours after the injection, fluorescein dye was observed in the sub-retinal space, between retinal pigment epithelium (RPE) and neurosensory retina. Histologic samples showed minimal damage due to the insertion of needle and there was no disorganization in the retina.

Conclusion: This study revealed that fluorescein can be injected by the micro-injector into the subretinal space accurately. It seems that this device has the capability to inject stem cells into the retina properly and can be used in animal models.
\end{abstract}

Keywords: Micro-injector, Stem cells, Subretinal space, Rat.

Received: Nov 14, $2019 \quad$ Accepted: Mar 1, 2021

How to cite the article: Hamid Aboutaleb Kadkhodaeian,Amir Salati , Hamidreza Sameni, Alireza Lashay. Design, fabrication and evaluation of the cell micro-injector for improvement of the quality of subretinal space injection with minimum damage. SJKU 2021;26(4):105-116.

Copyright (C) 2018 the Author (s). Published by Kurdistan University of Medical Sciences. This is an open access article distributed under the terms of the Creative Commons Attribution-Non Commercial License 4.0 (CCBYNC), where it is permissible to download, share, remix, transform, and buildup the work provided it is properly cited. The work cannot be used commercially without permission from the journal 


\section{طراحى، ساخت و ارزيابى دستَاه ميكرواينجكتور سلولى جهت بهبود كيفيت تزريق در فضاى زير شبكيه با حداقل آسيب}

حميد ابوطالب كدخداييان اوب، امير سلاطى '، حميدرضا ثامنى"، عليرضا لاشيئى "

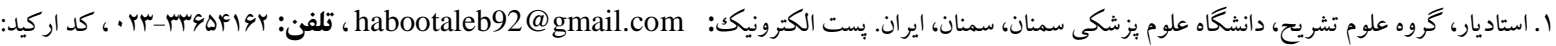
qVrr-QVrq_...r....

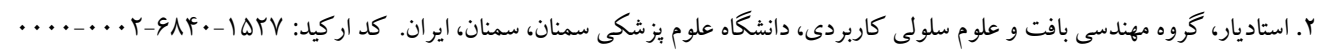
r. دانشيار، مركز تحقيقات سلول هاى بنيادى سيستم عصبى، دانشگاه علوم يزشكى سمنان، سمنان، ايران. كد اركيد:

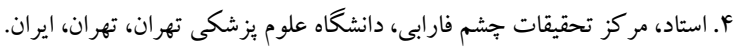

جكکטه

زمينه و هدف: تزريق صحيح سلول در روش هاى سلول درمانى يكى از مراحل مهـم و جـالش برانكيز در مطالعات حيوانى و

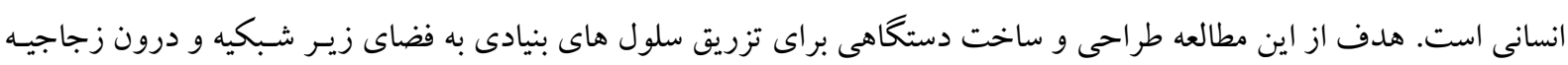

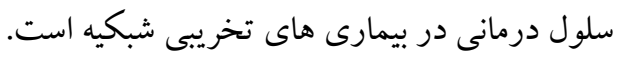

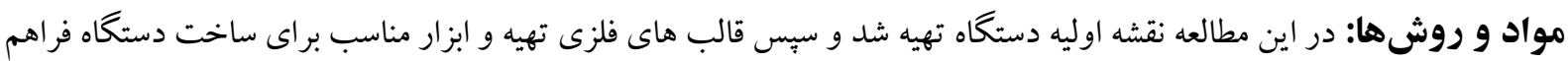

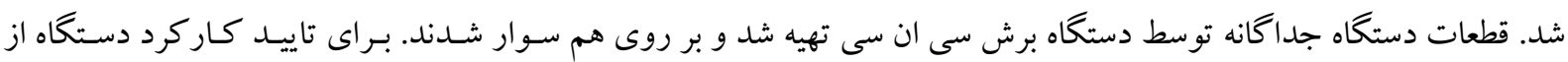

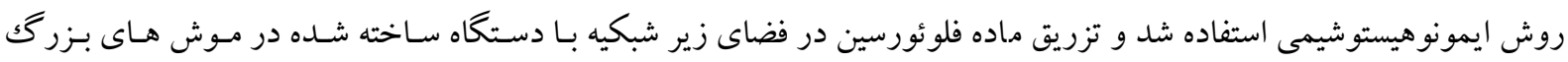

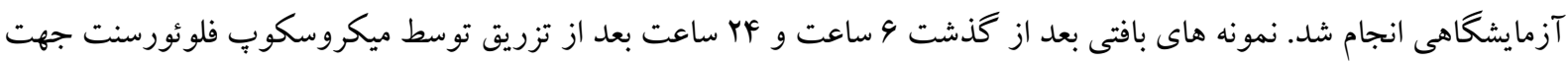
تزريق صحيح مورد بررسى قرار گرفتند.

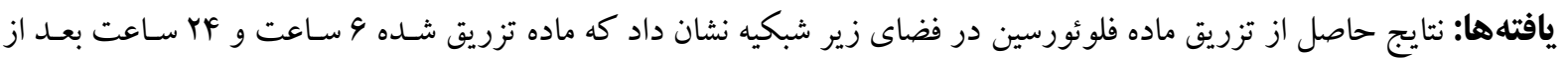

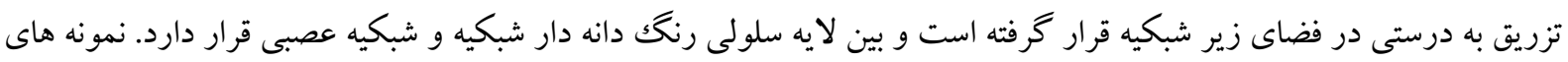

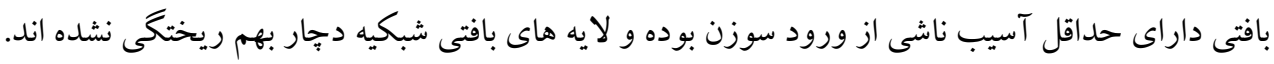

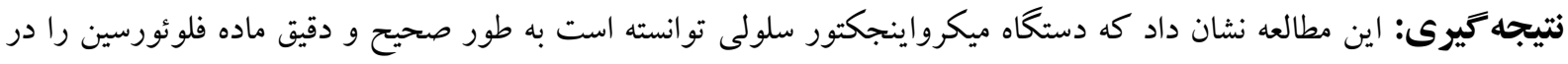

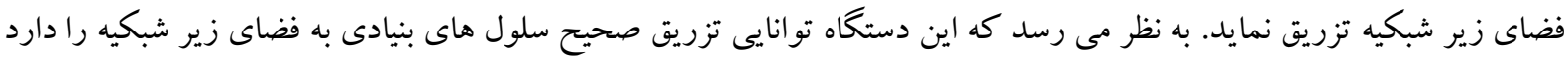
و مى تواند در مدل هاى حيوانى مورد استفاده قرار كيرد.

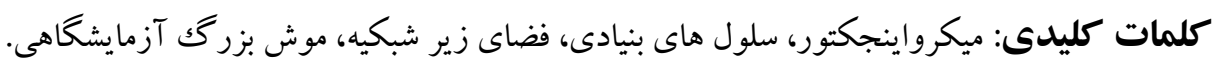

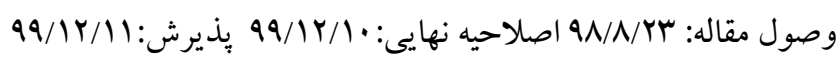


براى تزريق سلولى وجود دارد كه از وريد دمى براى تزريق

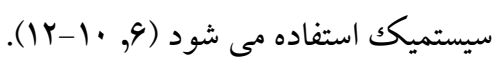

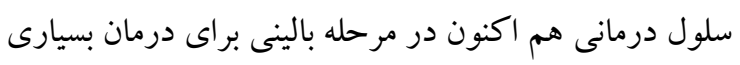

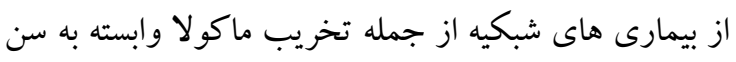
(نئوواسكو لار و آتروفيك)، استار كات، رتينيت بيخمنتوز

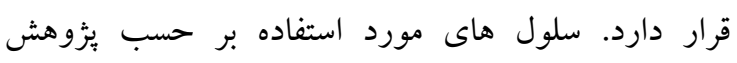
عetinal ( عبارتند از سلول هاى رنغك دانه دار شبكيه مشتق شده از سلول (Pigment Epithelium, RPE هاى بنيادى جنينى و يا سلول هاى القا شده يرتوان، سلول هاى بنيادى عصبى مشتق شده از جنين انسانى ( Human Central Nervous System Stem Cell, (HuCNS-SC انسانى و سلول هاى بنيادى اوتولو گوس مغز استخوان.

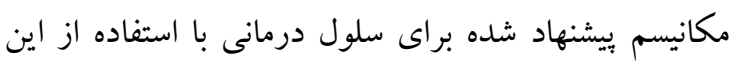

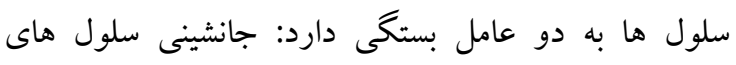

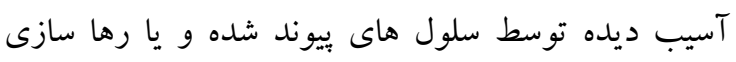
بايدار فاكتورهاى رشد كه موجب افزايش فعاليت سلول هاى شبكيه شود. سلول درمانى در فضاى زير شبكيه به

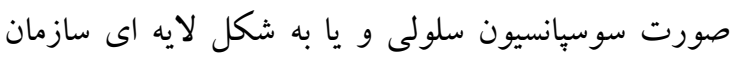

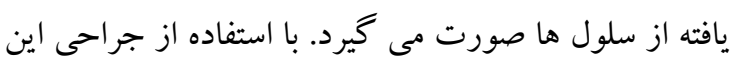

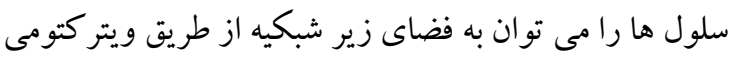

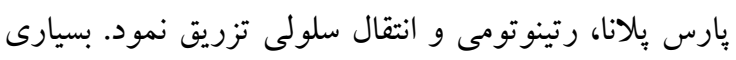
از مشكلات به دليل وسايل جراحى و تكنيك جر احى ايجاد

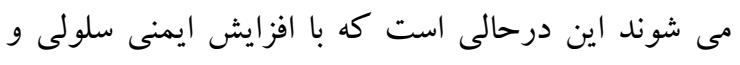

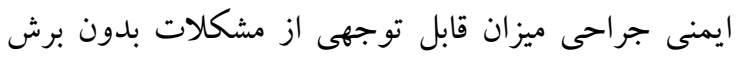
جراحى براى دسترسى بهتر به فضاى زير شبكيه برطرف

$$
\text { خو اهد شد (13, 14). }
$$

رساندن سلول هاى بنيادى به بافت هدف به طور دقيق، موثر

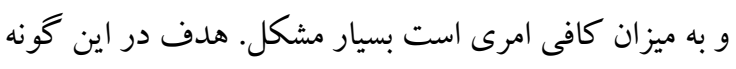

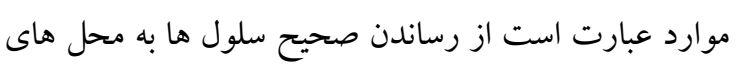

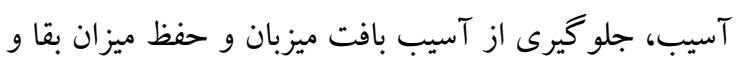

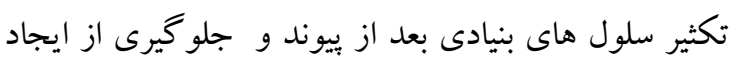
بدخيمى و تراتوما. مسيرهاى دسترسى و بييوند سلول هاى بئي
مقدمه تزريق سلولهاى بنيادى به درون جشم به طرق مختلف انجام مى شود اما بطور كلى دو روش براى تزريق سلول به درون جشم وجود دارد ا- تزريق درفضاى زير شبكيه ( sub intra (retinal space (vitreous ). تزريق در فضاى زير شبكيه نيز به سه شكل انجام مى شود; ا- دسترسى به فضاى زير شبكيه از طريق قرنيه

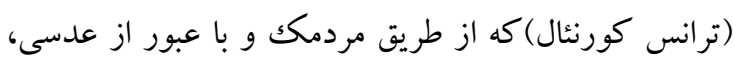

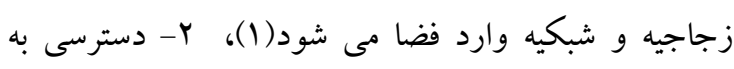

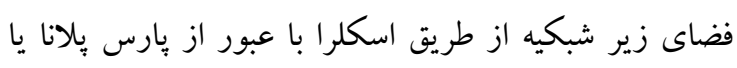

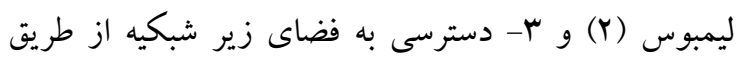

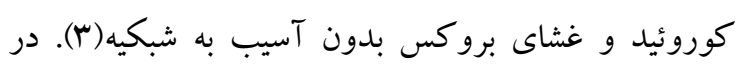
تزريق داخل زجاجيه اي غلظت بالايى از دارو و مواد تزريق

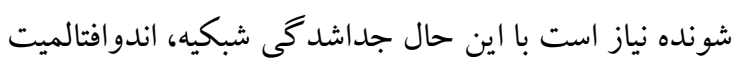
و خونريزى از عوارض اين روش است (Y-Y). ميانكين سهم

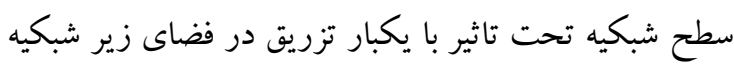

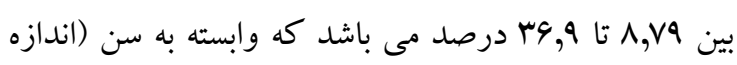

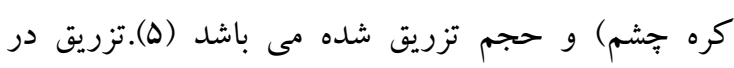
فضاى زير شبكيه روشى تهاجمى و وييجيده است.

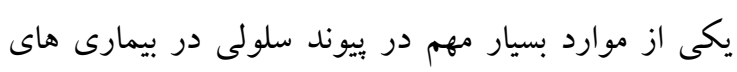

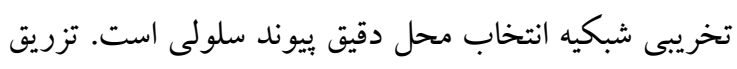
در فضاى زير شبكيه در بيمارى هاى تخريبى شبكيه از جمله تخريب ماكو لا وابسته به سن ( Age Related Macular (Degeneration, AMD (Retinitis Pigmentosa, RP محل آسيب موجب مهاجرت بيشتر سلول هاى بيوند شده مى شود(N). از طرفى فضاى زير شبكيه محيطى است كه از ماز

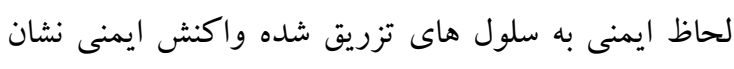
نمى دهد (V) با اين حال مطالعات نشان مى دهند كه موانع طبيعى از جمله لايه محدود كننده داخلى شبكيه و همجنين ماتين ماتريكس خارج سلولى آن در مهاجرت سلول هاى تزريق

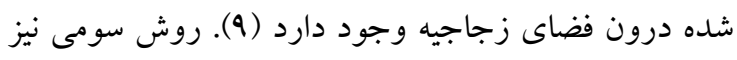


هاى مختلف استفاده نمود اما اين دستگاه هزينه بالايى داشته و به صرفه نيست. هم اكنون از تزريق كننده هاى زير شبكيه لامبرت و لاندرز با اندازه سوزن 20g و انتهاى انحنا دار به

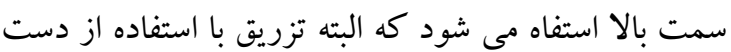

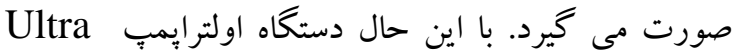
Pomp3, UMP3 تزريقات را دارد اما هزينه بالايى دارد و به صرفه نيست.

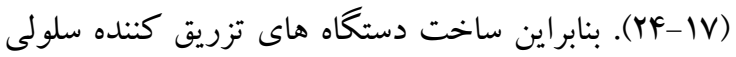

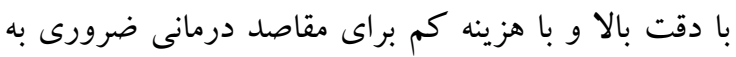

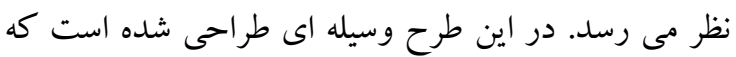

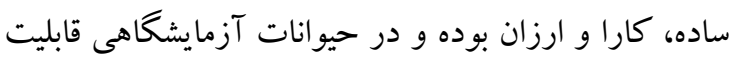
استفاده دارد. اين وسيله داراى سوزن تزريق 30g است كه دورد

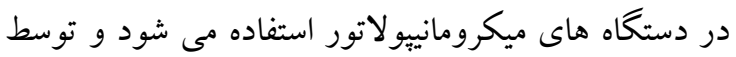
دست قابليت حركت دارد. مزيت اين طرح در داشتن قطعه اى است كه متحرك بوده و امكان حركت و تنظيم براى تزريقات در فضاى زير شبكيه و داخل زجاجيه توسط دست را فراهم مى سازد و بعد از ورود به فضاى مورد نظر نياز به دست اويراتور نيست و بنابراين درصد خطاى تزريق كاهش

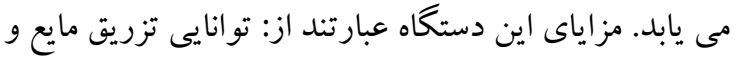
سلول در فضاى زير شبكيه و داخل زجاجيه، قابليت تزريق بصورت افقى و اوريب، قابليت حركت سوزن تزريق در مقياس ميكرومتر (كام حركت كوجگك)، قابليت حركت سوزن در مقياس سانتى متر (كام حركت بزرگ)، قابليت تنظيم ارتفاع سرنگك، تزريق مايع و سلول بدون مترن ايجاد حركت و لرزش در سوزن تزريق، قابليت نصب دوربين و ادوات سيستم تزريق خود كار. همجنين به دليل استفاده از

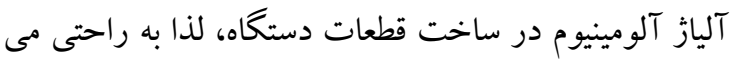

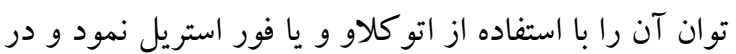
محيط هاى كشت و يا اتاق جراحى استفاده كرد.

\section{مواد و روشها}

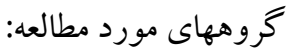

بنيادى بر حسب مقاصد يثوهشى متفاوت است. به طور مثال تزريق داخل وريدى يكى از ساده ترين روش هاى رساندن سلول هاى بنيادى است اما در اين روش اثربخشى سلول هاكم بوده و ميزان كمى از سلول ها به محل ضايعه مى رسند

تاكنون استاندارى براى تعيين حجم، غلظت و سرعت تزريق سلول هاى بنيادى در كار آزمايى هاى بالينى تعريف نشده

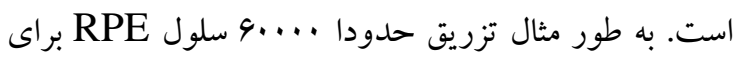
يوشش كامل ماكو لا جهت حفظ ديد مركزى بر آورد شده

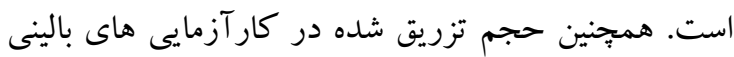

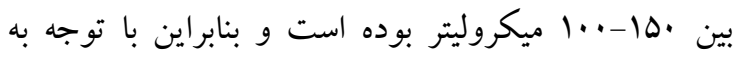

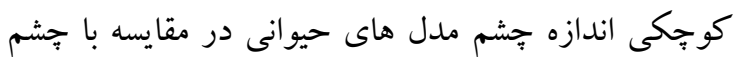

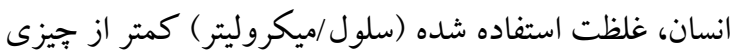
است كه در مطالعات حيوانى استفاده مى شود (^). تزريقات

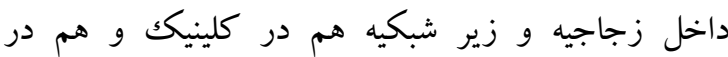
آزمايشكاه هاى تحقيقاتى براى تزريق مواد مختلف از جمله داروها و محلول ها و يا سلول ها مورد استفاده است(V). جنين تزريقاتى مى تواند به صورت دستى و از طريق قرار دادن يكك سوزن به درون صلبيه جشم و ايجاد سوراخ از طريق آن به درون زجاجيه يا زير شبكيه انجام شود. روش هاى مختلف تزريق نيازمند قرارگيرى صحيح سوزن در بهر فضاى مورد نظر است. سوزن تزريق را مى توان از طريق

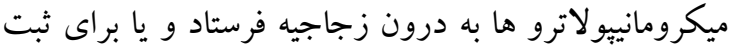
فعاليت الكتريكى سلول هاى شبكيه نزديك شبكيه قرار داد. جنين وسايلى نيازمند قرارگيرى درست سوزن در شبكيه است. دستگاه هايى كه جنين تو انمندى را دارند كران بوده و براى استفاده در حيوانات كوجّك آزمايشكاهى مناسب

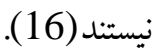

تزريقات داخل جشمى كه به صورت خودكار انجام مى شود در مقايسه با تزريقاتى كه با استفاده دست انجام مى دوري شود داراى ايمنى بيشتر و دقت تزريق بيشترى هستند.

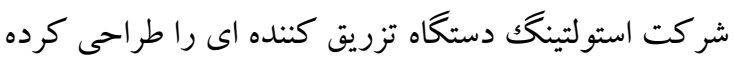
است كه شبيه به استريوتاكس بوده و مى توان براى نمونه 
ميله افقى و شيار بالا به بايب الاكلنَّى از طريق سوراخ هايى ديى

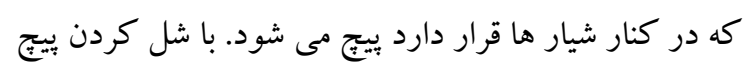

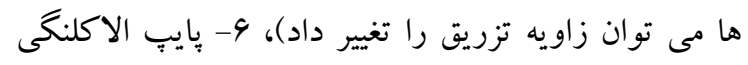

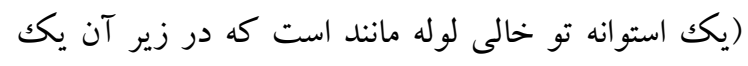
زائده قرار ارد. اين زائده به مفصل دو سويه متصل مى شوده ماند

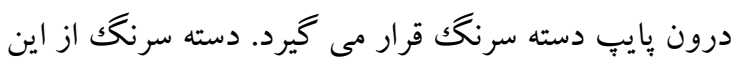
طريق مى تواند به عقب و جلو (كام بزرگك) و به صورت دورانى حركت كند و در جاى خود محكم شود)، V- V- دسته

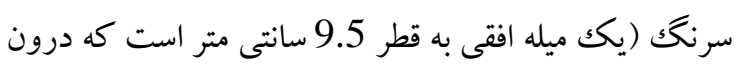

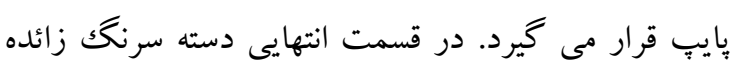

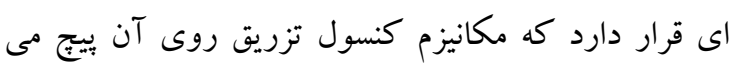

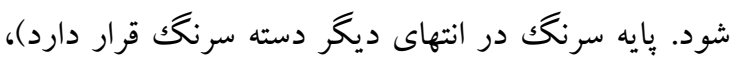

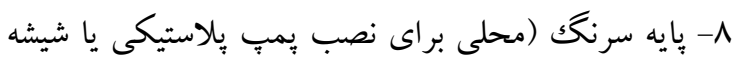

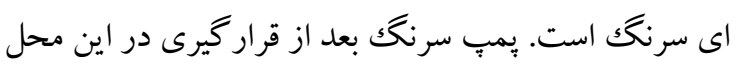

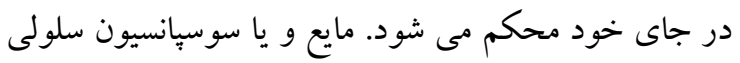

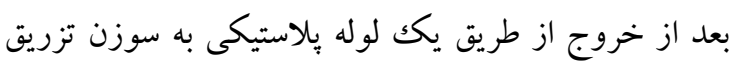

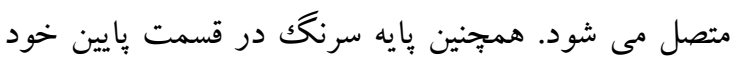

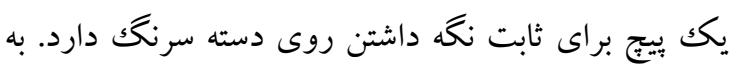
اين ترتيب عمل تزريق مايع و سلول بدون حركت دادن دادن

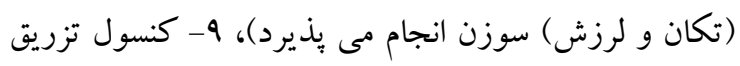

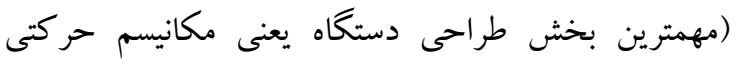

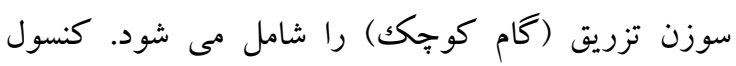
تزريق روى دسته سرنك قرار مى گيرد و داراى يك كن آلت متحرك بنام راهبر سوزن است. راهبر سوزن در انتهاى كنسول قرار مى گيرد و سوزن تزريق روى راهبر بيّج شده و ثابت مى ماند. روى بدنه راهبر يكك سوراخ رزوه دار قرار

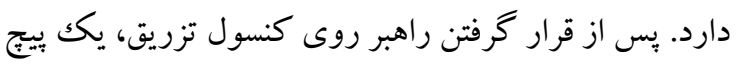
بلند از درون سوراخ هاى تعبيه شده در كنسول تزريق و وردي

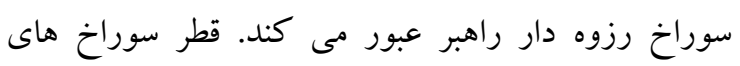

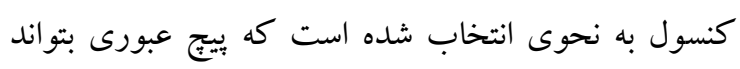

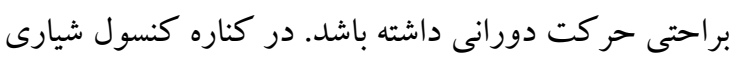

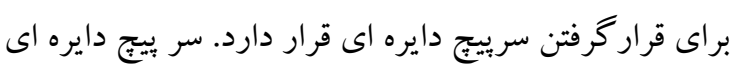

تمامى روش هاى مورد استفاده در اين تحقيق بر اساس (The Association for the Research دستور العمل دوردين in Vision and Ophthalmology,ARVO) استفاده از حيو انات در تحقيقات جشم انجام شد و ملاحظات اخلاقى بر اساس كميته اخلاق دانشگاه علوم بزشكى سمنان

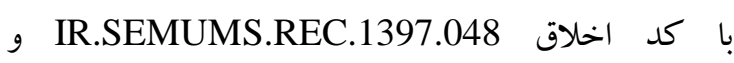
همجنين دستور العمل اخلاقى هلسينكى سال 19VD مد نظر

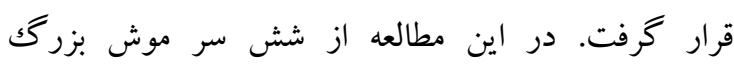

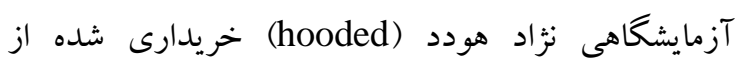

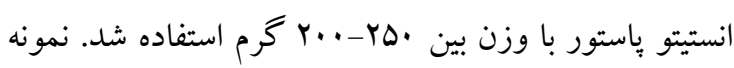

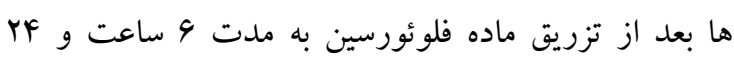
ساعت بعد از تزريق مورد مطالعه قرار گرفتند. طر احى و ساخت دستگاه:

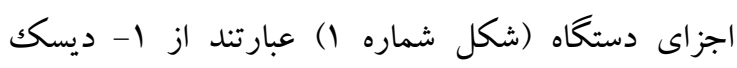

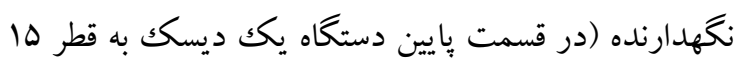

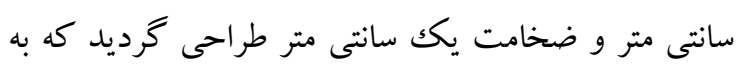

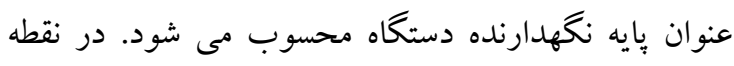

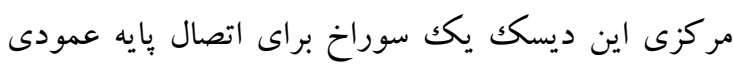
درنظر گرفته شده است)، ب- ميله عمودى (اين ميله به مركز

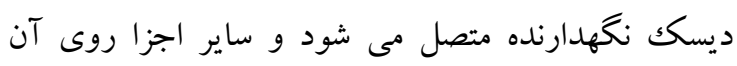

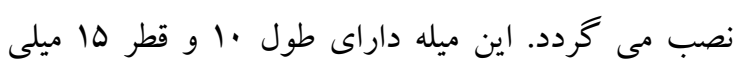

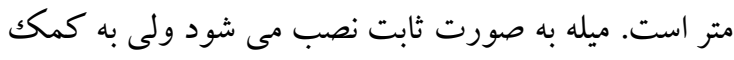

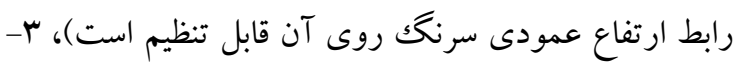
مكعب رابط (مكعب رابط با ابعاد 2.5 در 2.5 در 4.5

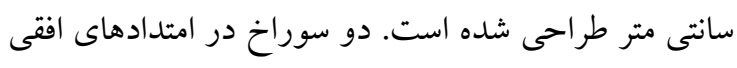
و عمودى مكعب براى ميله هاى افقى و عمودى ايجاد شده است. از طريق اين مكعب ارتفاع عمودى و افقى سوزن قابل مديل

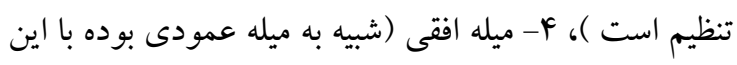

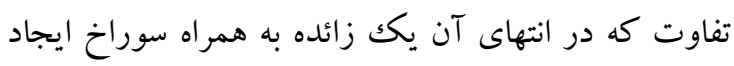

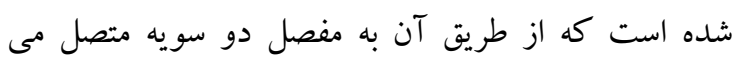

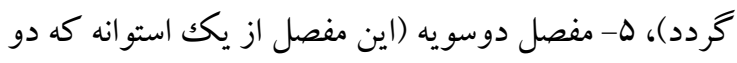
سر آن داراى شيار است تشكيل شده است. شيار پايين به دوديه

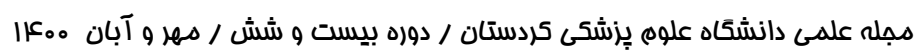


تزريق تاييد شد. بلافاصله بعد از تزريق و بايان جراجى bleb از پماد جشمى حاوى باسيتراسين، نئومايسين و يلى ميكسين استفاده شد تا ريسك عفونت و آسيب قرنيه كاهش يابد.

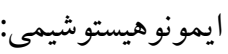
بعد از تزريق فلوئورسين، بر اساس روش achalinskaM و

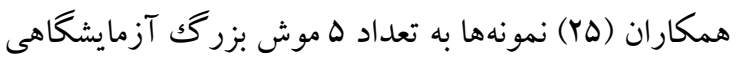

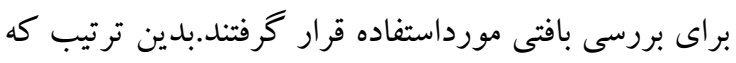
ابتدا نمونه ها با استفاده از تزريق داخلى بردي صفاقى كتامين

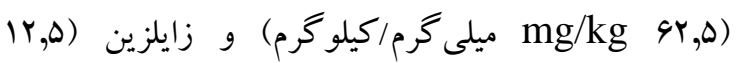

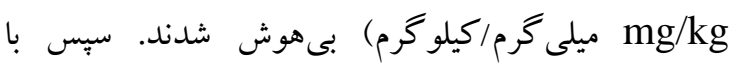

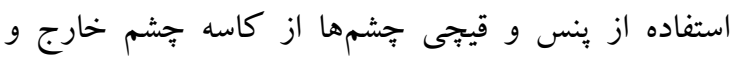

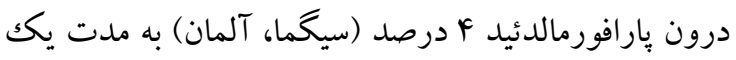
شب قرار داده شدند. در روز بعد نمونهها از درون

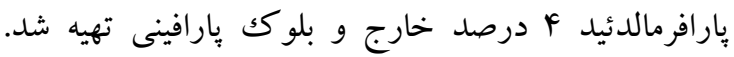

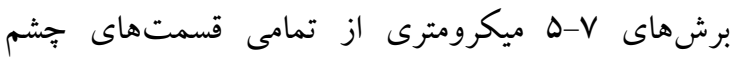
بهصورت سريالى تهيه شد. براى رديابى ماده فلوئورسين

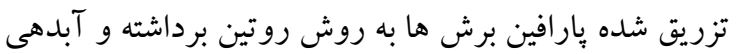

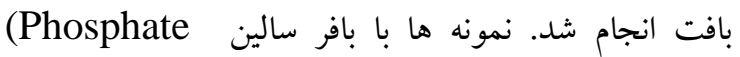
شuffer Saline, PBS) مدت ا دقيقه در دماى اتاق يراكسيدهاى درونى بلاكى شدند. نمونه ها با PBS شستشو داده شد و اسيد

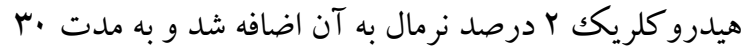
دقيقه در دماى TV درجه قرار گرفت. نمونه ها با بافر بورات شسته شد و ..1 ميكروليتر از ترييسين خرم به نمونه ها اضافه

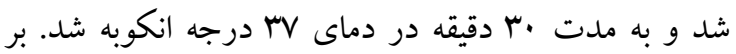
روى نمونه ها ..1 ميكروليتر از محلول بلاكك كننده به مدت ها دقيق در دماى TV درجه ريخته شد. در مرحله بعدى، بعد بلد

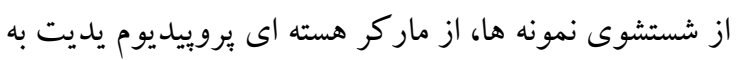

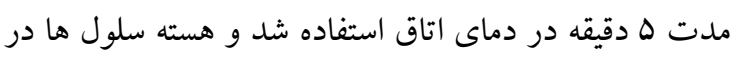

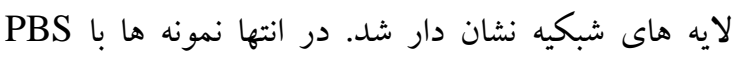

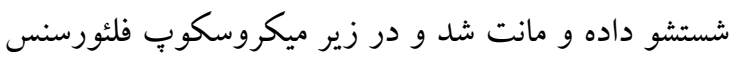
مشاهده شد.

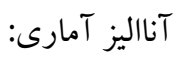

علاوه بر ايجاد حركت دورانى مانع از حركت افقى بيج مى

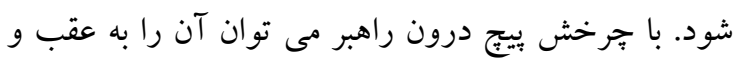
جلو هدايت كرده و عمق تزريق را بصورت دقيق (كام نورن كوخكك) تنظيم نمود). تزريق به فضاى زير شبكيه توسط دستخاه طراحى شده: موش هاى بزرك كآزمايشگاهى توسط كتامين 62.5 mg/kg و زايلزين mg/kg 12.5 از طريق داخل صفاقى تونى بيهوش شدند. همجنين مردمكك جشم ها توسط قطره فنيل

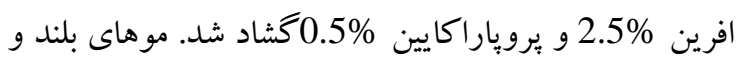
زائد اطراف جشم حيوان برداشته شد تا ديد مناسب و خوبى براى جشم و فوندوس فراهم شود. اندازه و يبشرفت گثشاد

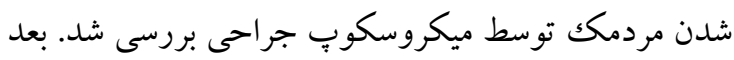

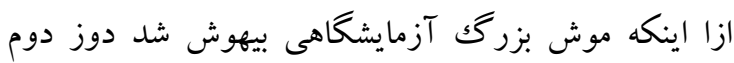

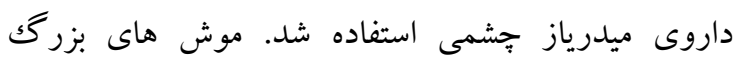

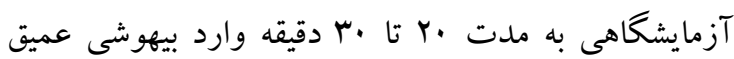
شدند و اين زمان مناسبى براى تزريق در فضاى زير شبكيه

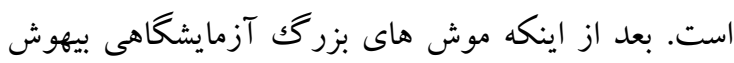

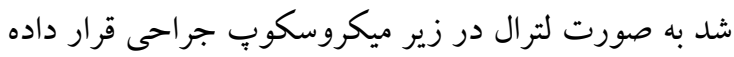
شدند و با دست ديخر نغه داشته و يوزيشن مناسب داده شد.

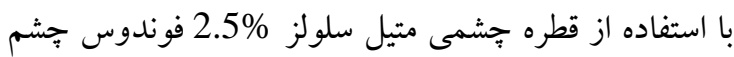
مشاهده شد. با استفاده از ينس و قيجى ظريف دئ در كره جشم برش كو پكى ايجاد شد و به آرامى لايه هاى زيرين باز شد

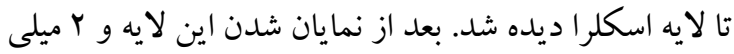
متر در خلف ليمبوس در موقعيت ساعت ب موقعيت سوزن تثبيت شد و با سوزن هميلتون (30G) با استفاده از قطعه متحرك دستگاه ميكرواينجكتور به آرامى وارد فضاى زير

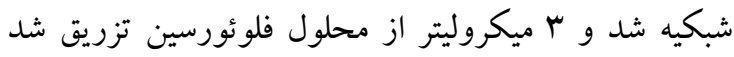

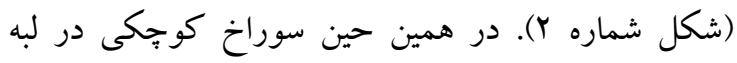

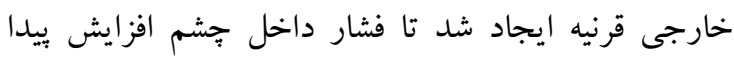
نكند. بعد از اتمام تزريق مجدد توسط قطعه متحرك سك، سوزن به آرامى خارج شد و محل برش لايه ها با استفاده از نخ -

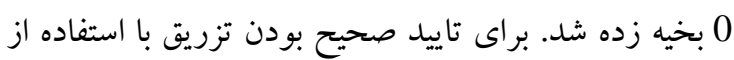

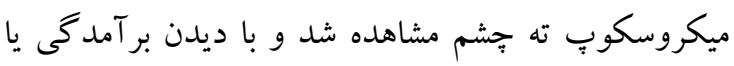




$$
\text { طر احى و ساخت دستخاء: }
$$

همانطور كه در شكل (1) به تفصيل نشان داده شده است داحت

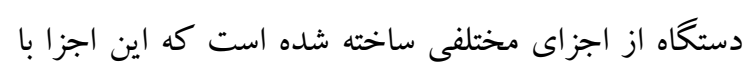

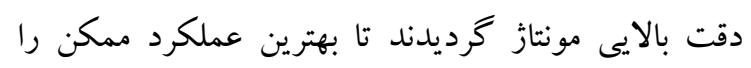

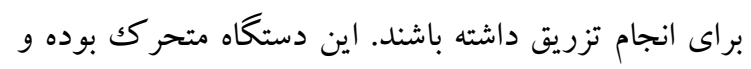

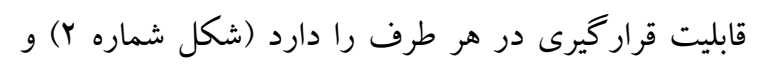

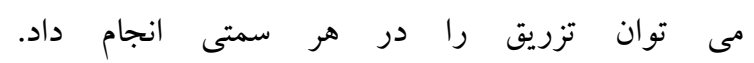

جامعه مورد مطالعه در اين تحقيق شش سر موش بزرگك

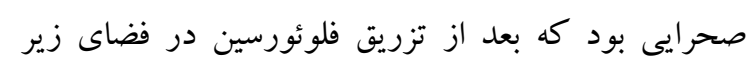

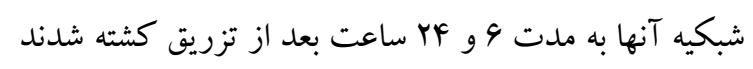

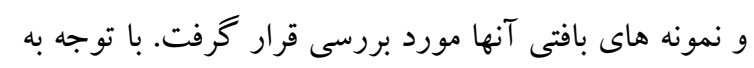

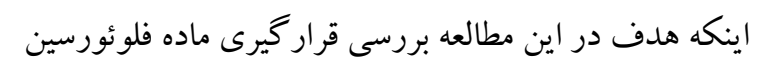

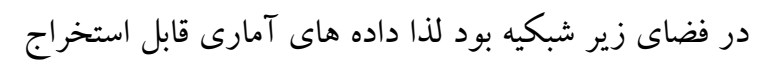

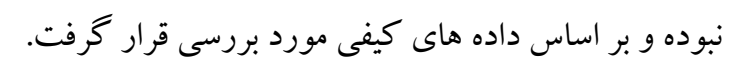

يافته ها

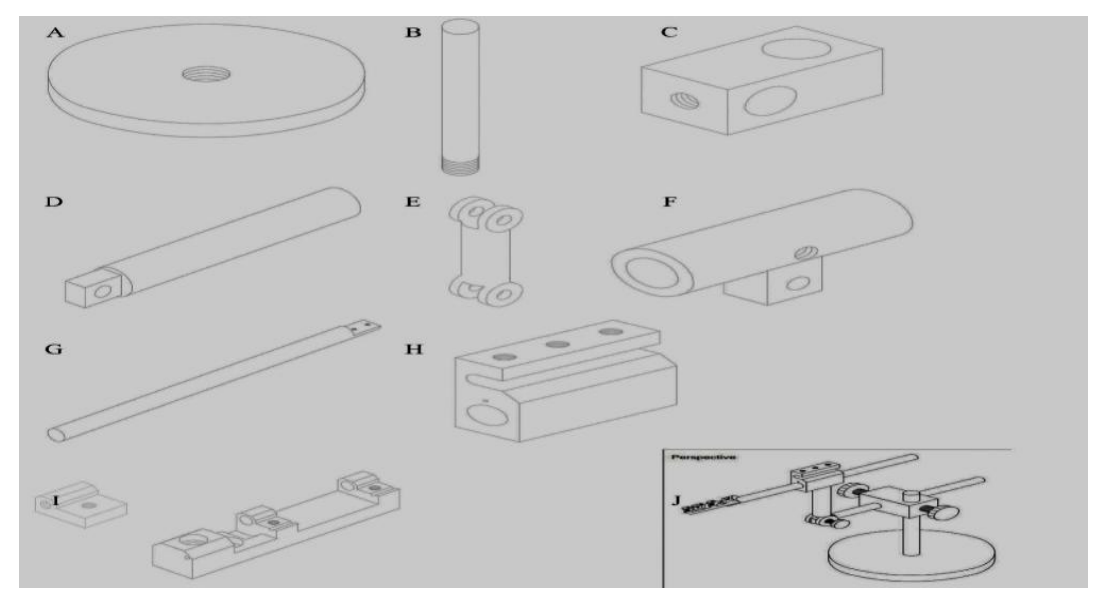

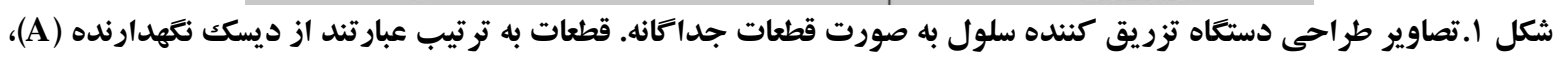

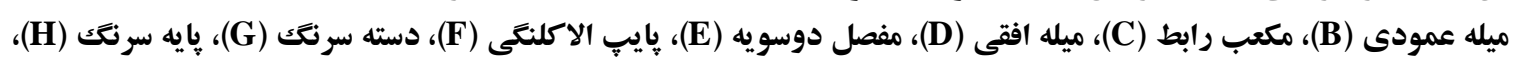
كنسول تزريق (I). تصوير نهايى قطعات جدا بصورت يكجا در تصوير J د ديده مي شود.
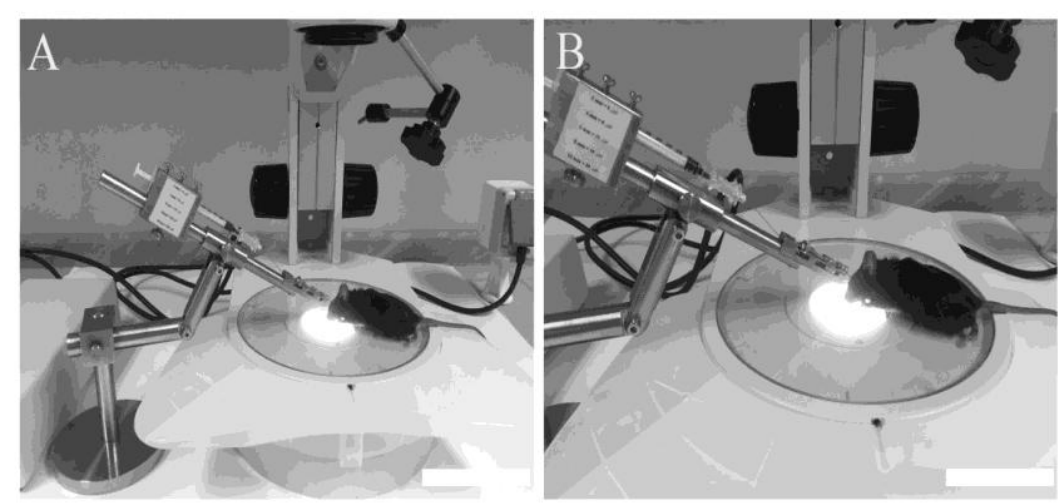

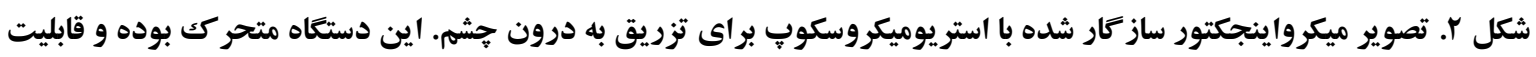

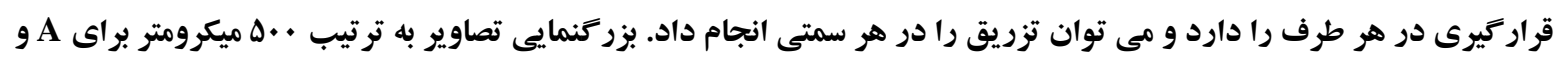

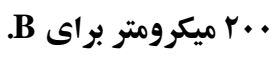

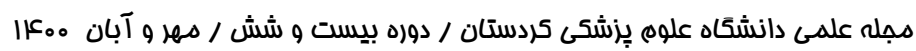


اين ماده در فضاى زير شكبيه بين لايه رنگدانه دار شبكيه و

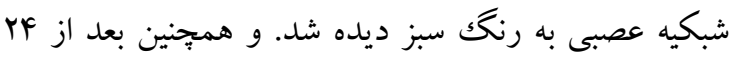
ساعت از تزريق (شكل r D-F) نيز فلوئورسين در فضاى زير شبكيه بخوبى ديده شد. اين روش اين امكان را فراهم مى سازد تا بتوان سلول هاى بنيادى را به همين ترتيب در فضاى زير شبكيه تزريق نمود.
تزريق به فضاى زير شبكيه: براى درستى تزريق در فضاى زير شبكيه از تزريق ماده فلوئورسين در فضاى زير شبكيه موش هاى بزرگ

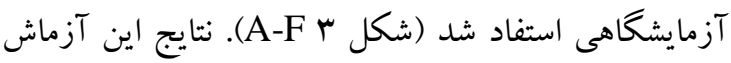
نشان داد كه تزريق ماده فلوئورسين در فضاى زير شبكيه با استفاده از دستخاه طراحى شده ميكرواينجكتور موثر و كارا بوده است جنانكه 4 ساعت از بعد از تزريق (شكل r A-C)

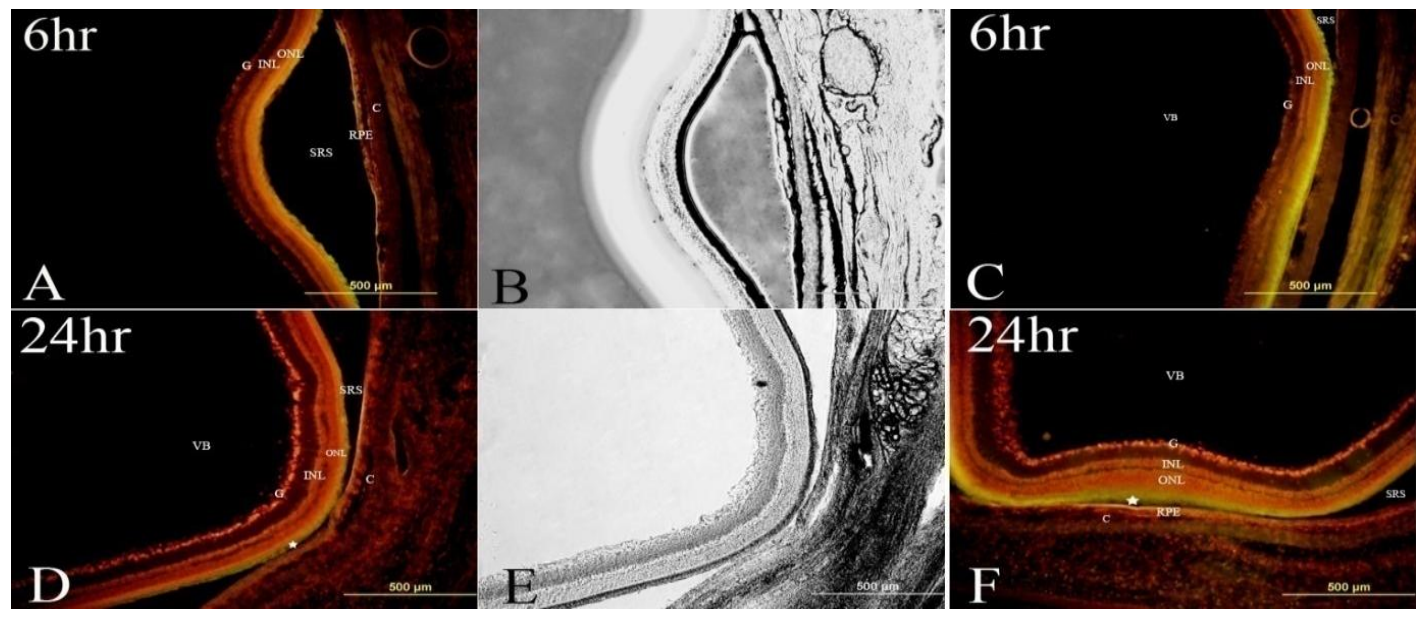

شكل r. ايمونوهيستوشيمى نشان دهنده تزريق فلوئورسين به فضاى زير شكبيه در موش هاى بزركى آزمايشعاهى و و و T ساعت بعد از تزريق. تصاوير A-C نشان دهنده تزريق فلوئورسين 9 ساعت بعد از تزريق مى باشد و تصاوير D-F نشان دهنده تزريق فلوئورسين

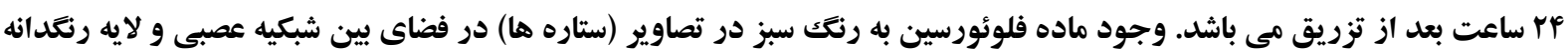

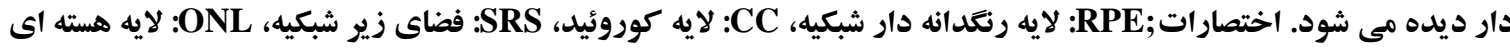

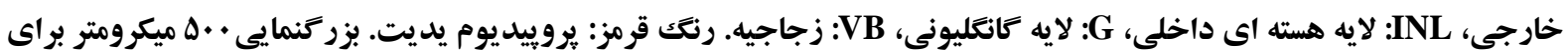
A-F

تنظيم ارتفاع سرنگك، 9- تزريـق مـايع و سـلول بـدون ايجـاد حركت و لرزش در سوزن تزريق، V- قابليت نصسب دوربسين

$$
\text { و ادوات سيستم تزريق خود كار. }
$$

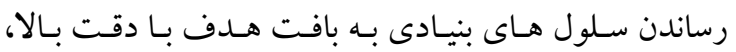
راندمان بالا و موثر بسـيار مشـكل اسـت. هـدف از ايـن كـار عبارت است از: ا- رساندن دقيق سلول ها در مناطق آسـيب ديده، Y- دورى از آسيب به بافت ميزبـان و r- حفـظ بقـا و تكثير سـلول هـاى بنيـادى بعـــ از بيونـــ (ها ). بـراى درمـان شـبكيه راهرهـاى رسـاندن سـلول عبار تنــــ از ييونسد داخــل زجاجيه، فضاى زير شبكيه (V)، راه بينـايى و وريــ بينـايى و حتى داخل شبكيه ای. با توجه به اينكه فضاى زير شبكيه راه
بحث در اين مطالعه دستخاهى براى تزريق سـلول هـاى بنيـادى بـهـ فضاى زير شبكيه و داخل زجاجيه طراحى شـــ تزريـق مـاده فلوئورسنت با استفاده از اين دستخاه در مـدل حيـوانى نشـان داد كه اين دستگًاه به خوبى مى تواند وارد فضاى زير شبكيه شده و ماده مورد نظر رادر اين فضا تزريق نمايد. مزاياى اين دستگاه عبارت است از: ا- توانايى تزريـق مـايع و سـلول در فضـاى زيــر شـبكيه و داخــل زجاجيـه، ب- قابليـت تزريـق بصورت افقى و اوريب، ب- قابليت حركت سوزن تزريـق در مقياس ميكرومتر (كام حركت كو جكك)، \&- قابليت حركت سوزن در مقياس سانتى متر (كام حركت بزرگك)، ه- قابليت 
شبكيه نيز توسط دست انجام مى شـود لـذا بعـد از ورود بـهـ

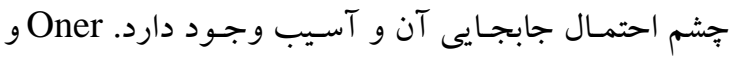

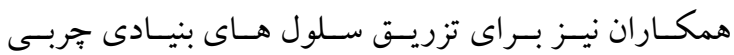
در(Adipose Derived Stem Cells, ADSCs)

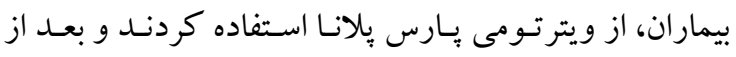

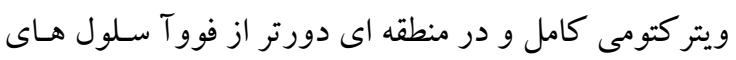

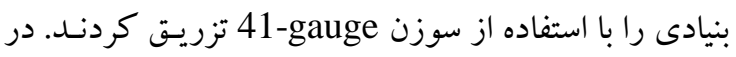
اين روش نيز تزريق به روش دستى و توسط جراح انجام شد

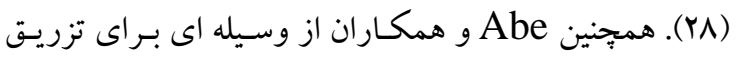

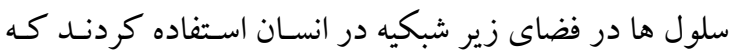

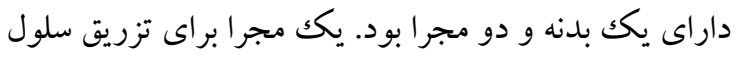
و ديخرى براى تزريق سالين. البتهـ بـراى استفاده از آن بايسـ

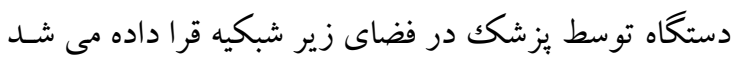
و توسط إيراتور سالين و يا سلول به فضاى زير شبكيه تزريق

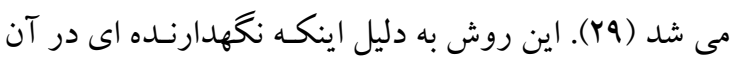

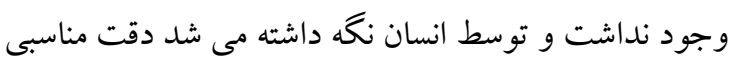

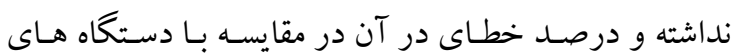

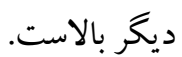
در روش ديخر براى حـذف و يـا كمى كردن خطـاى دست انسانى مى توان قبل از ورود سوزن اصلى تزريق ابتدا كـانولا

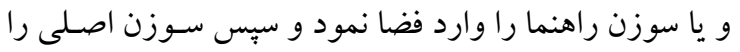
از طريق آن به فضاى مورد نظر رسـاند(·r). بطور مشابه در

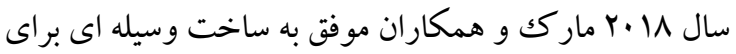
تزريق سلول هاى بنيادى مشتق از بافت بنــ نـاف انسـانى بـهـ

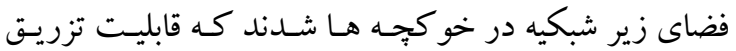
نرمال سالين را نيز داشته و در واقع از دو لايسن بـراى تزريـق

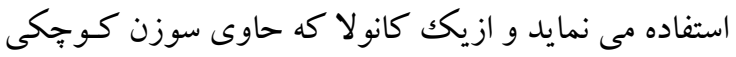
است براى تزريقات فوق كوروئيسدى اسـتفاده مى كنـد. از طريق اين سوزن دستكاه قابليت رسيدن به فضاى زير شـبكيه

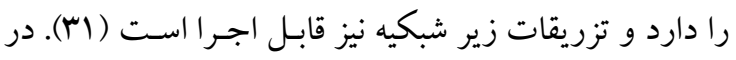

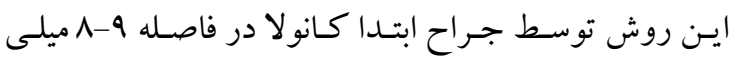

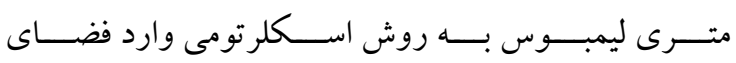

بهترى اسـت و دقـت بـالاترى داشـته و ميزان تمـايز سـلولى

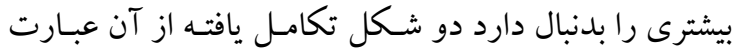

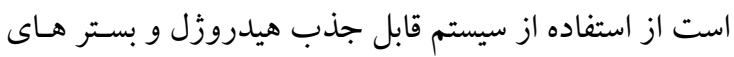

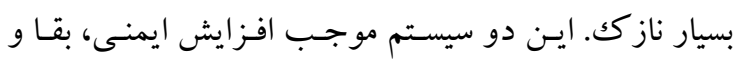

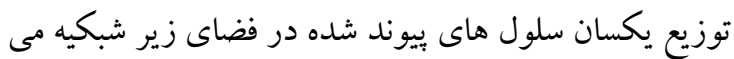

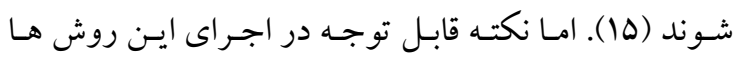

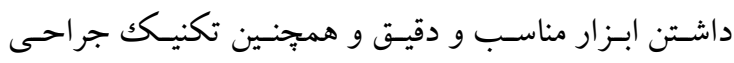

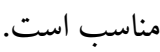
در بسيارى از موارد تزريقات در داخل جشم به روش دستى انجام مى شود و جراح و يا فرد محقق با دست سوزن راوارد

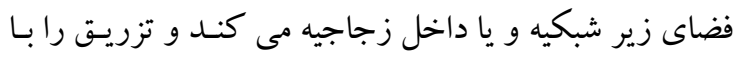

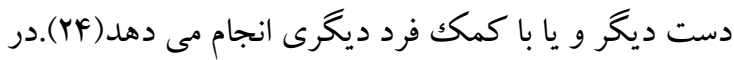

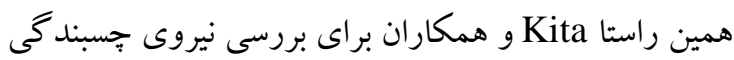
شبكيه در خر گحوش از يـك ميكروبييـت شيشـه اي استفاده كرد و از Y ميلى مترى خلف ليمبـوس وارد جشـم شـد و بـهـ فضاى زير شـبكيه رسيد. ايـن محققين بـراى تزريق نرمـال

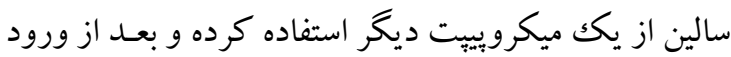
به فضاى زير شبكيه به يكك سيستم اندازه گيرى كننده فشار متصـل شـد و تزريق بـا سـرعت ml/hr 0.1 انجـام دادو بـاـا

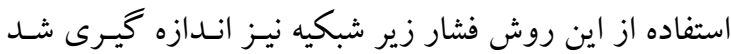

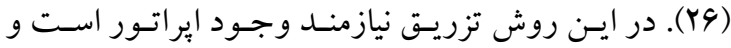

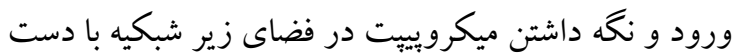
است و لذا احتمال جابجايى و خطا افزايش مى يابد. همجنين در سال Fernandez Y. IV فناندز و همكـارانش موفق بـه

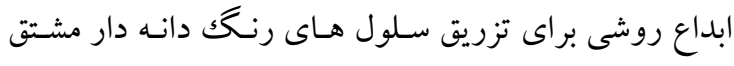
شده از سلول هاى بنيادى جنينى به فضاى زير شبكيه شـدند

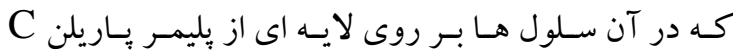
قرارداده شدند و سِس بـا استفاده دستـاه ابـداعى آنها بـهـ درون شبكيه بيوند زده شد. با استفاده از اين تكنيكك امكان

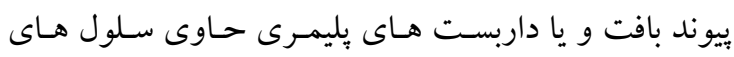

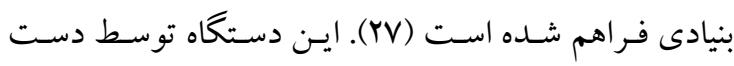
جراح و يا إيراتور نكه دارى مى شود و ورود به فضـاى زيـر

هبله علمى دانشكاه علوه بِزشكى كردستان / دوره بيست و شش / دعر و آبان م.ع|| 
شود مى توان با دقت بالا وارد فضاى زير شبكيه شد. در سال Haltman و همكاران دستخاهى براى تزريق

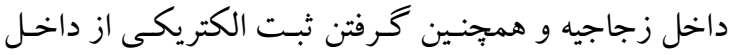

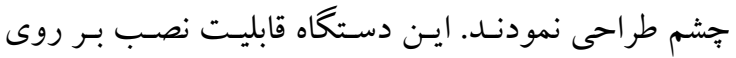

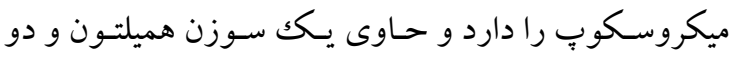
سوزن براى هدايت سـوزن اصلى و همجِنين كانولايى كه

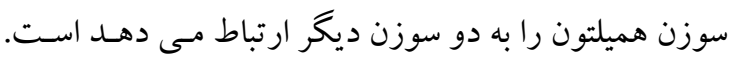

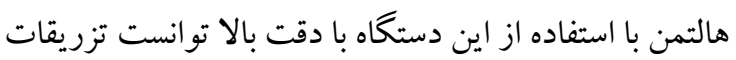
داخل زجاجيه اي را انجام دهد (19). با اين حال اين تزريق

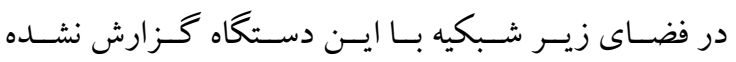

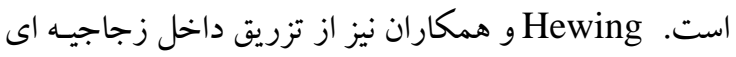

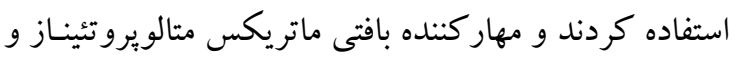

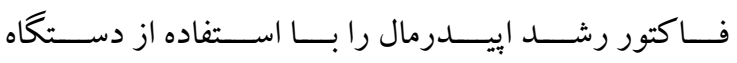

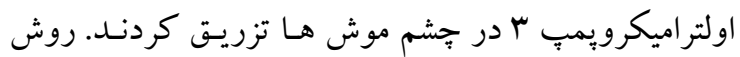
تزريق آنها همانند روش Kita و همكاران بود (Yr). در ايـن روش تزريقات به صورت كنترل شده و با دقت بالا در جشم تزريق شده است. بطور مشابه Christaina و همكاران براى

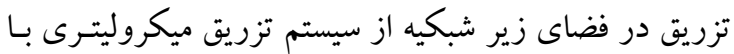
يمب UMP-III استفاده كردند. در اين مطالعه براى رسيدن

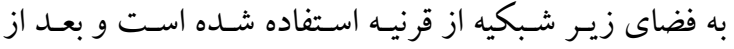
كذراندن سوزن از قرنيه، از طريق مردمك به شبكيه رسيده اند كه البته در اين روش احتمال آسيب عدسى بسيار بالاست Xie و همكاران براى تزريـق رتروويـروس بـه فضـاى (YF)

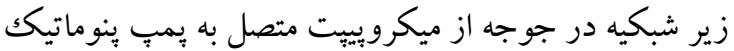
با فشار مثبت استفاده كردند (WF).

\section{نتيجه كيرى}

نتايج حاصل از اين تحقيق نشان داد با استفاده از دستكاه

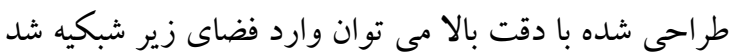

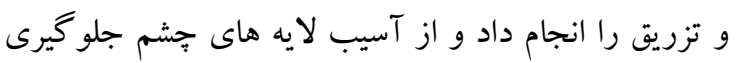
كرد. در اين روش اثر دست فرد محقق بسيار كم بوده و لذا

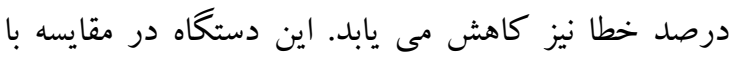

سوير اكوروئيد شده و به انـدازه هـr ميلـى متر در ايـن فضـا بيش بـرده مس شـود و بـراى اينكه كانولا در حسين تزريق

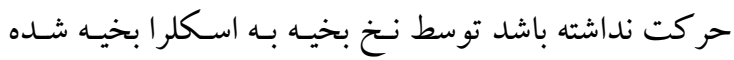
اسـت و ســس سـوزن اصـلى تززيـق از طريـق كـانو لا وارد فضاى زير شبكيه شـده اسـت و تزريـق انجـام گرفتـه اسـت

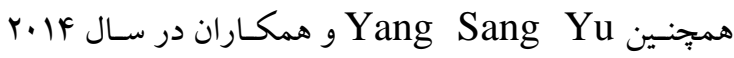
موفق به ساخت سوزنى شدند كه توانايى تزريق به فضاى زير شبكيه را داشت و حداقل آسيب به شبكيه را ايجاد مى كنـد. اين سوزن به صورت منحنى بـوده و داراى زاويـه ها درجـه

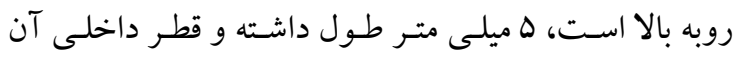

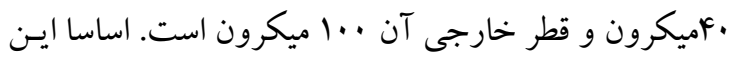
وسيله براى تزريق دارو بـه فضـاى زيـر شـبكيه سـاخته شـده

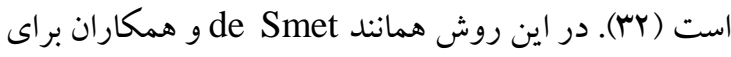

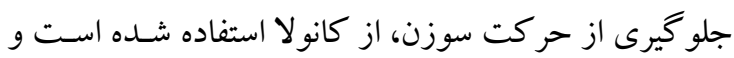
به بافت اطر اف بخيه زده شده است تا از حركات اضـافى و آسيب جلو گيرى شود و سبس سوزن طراحى شده از طريق

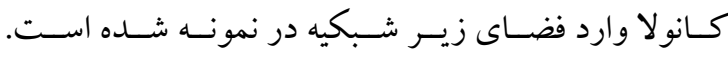
Schwartz و همكاران نيز سلول هاى RPE مشتق از سـلول هاى بنيادى جنينى را به فضاى زير شبكيه تزريق كردند. اين محققين براى رسيدن به اين فضا از ويتر كتومى يـارس هِلانـا

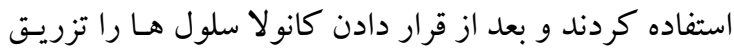

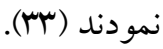
روش سومى نيز وجود دارد كه در آن مس تـوان اثر دسـت انسانى را به حداقل ممكن رساند و خطا و آسيب ناشى از آن را به كمترين حد ممكن رسـاند. در ايـن روش مسى توان از

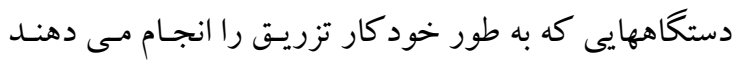

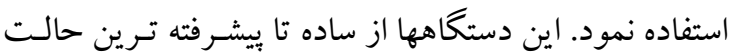
مى تواند بطور خود كـار وارد فضـاى زيـر شـبكيه شـوند و

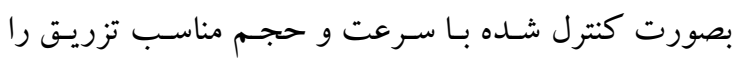

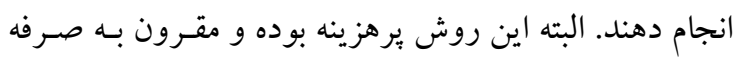

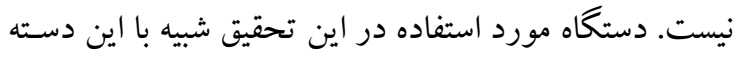

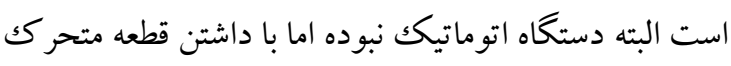

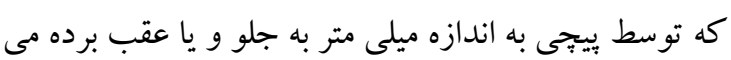




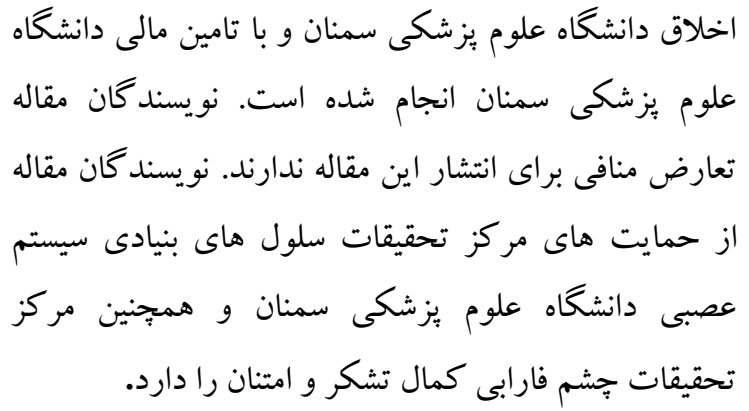

1.Qi Y, Dai X, Zhang H, He Y, Zhang Y, Han J, et al. Trans-corneal subretinal injection in mice and its effect on the function and morphology of the retina. PloS One. 2015;10(8):e0136523.

2.Mühlfriedel R, Michalakis S, Garrido MG, Biel M, Seeliger MW. Optimized technique for subretinal injections in mice. Retinal Degeneration: Springer; 2012. p. 343-9.

3.Parikh S, Le A, Davenport J, Gorin MB, Nusinowitz S, Matynia A. An alternative and validated injection method for accessing the subretinal space viaa transcleral posterior approach. J Vis Exp. 2016(118):e54808.

4.Rakoczy PE, Meaghan J, Nusinowitz S, Chang B, Heckenlively JR. Mouse models of age-related macular degeneration. Exp Eye Res. 2006;82(5):741-52.

5.Dureau P, Legat L, Neuner-Jehle M, Bonnel S, Pecqueur S, Abitbol M, et al. Quantitative analysis of subretinal injections in the rat. Graefes Arch Clin Exp Ophthalmol. 2000;238(7):608-14.

6.Siemann DW, Chaplin DJ, WalickePA. A review and update of the current status of the vasculaturedisabling agent combretastatin-A4 phosphate (CA4P). Expert Opin Investig Drugs. 2009;18(2):18997.

7.Peng Y, Tang L, Zhou Y. Subretinal Injection: A Review on the Novel Route of Therapeutic Delivery for Vitreoretinal Diseases. Ophthalmic Res. 2017;58(4):217-26.

8.Jones MK, Lu B, Girman S, Wang S. Cell-based therapeutic strategies for replacement and preservation in retinal degenerative diseases. Prog Retin Eye Res. 2017;58:1-27.

9.Johnson TV, Bull ND, Martin KR. Identification of barriers to retinal engraftment of transplanted stem cells. Invest Ophthalmol Vis Sci. 2010;51(2):960-70.

10.Chung JK, Park TK, Ohn YH, Park SK, Hong DS. Modulation of retinal wound healing by systemically administered bone marrow-derived mesenchymal stem cells. Korean J Ophthalmol. 2011;25(4):268-74.

11.Li Y, Atmaca-Sonmez P, Schanie CL, Ildstad ST, Kaplan HJ, Enzmann V. Endogenous bone marrow-derived cells express retinal pigment epithelium cell markers and migrate to focal areas of RPE damage. Invest Ophthalmol Vis Sci. 2007;48(9):4321-7.

12.Demuth $\mathrm{T}$, Berens ME. Molecular mechanisms of glioma cell migration and invasion. $\mathrm{J}$ Neurooncol. 2004;70(2):217-28.

13.Aboutaleb HK, Tiraihi T, Ahmadieh H, Ziaei HA, Daftarian N, Taheri T. Survival and Migration of Adipose-Derived Stem Cells Transplanted in the Injured Retina. Exp ClinTransplant. 2018;16(2):20411.

14.Schwartz SD, Nagiel A, Lanza R, Blumenkranz MS. Cellular Therapies for Retinal Disease 2017; 6(1): 4-11.

15.Wang J, Jokerst JV. Stem cell imaging: tools to improve cell delivery and viability. Stem cells Int. 2016;1(2):20-27.

16.Hultman D, Newman EA. A micro-advancer device for vitreal injection and retinal recording and stimulation. Exp Eye Res. 2011;93(5):767-70.

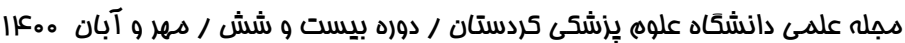


17.Cheah M, Fawcett JW, Andrews MR. Dorsal Root Ganglion Injection and Dorsal Root Crush Injury as a Model for Sensory Axon Regeneration. J Vis Exp. 2017;4(123):12-19.

18.Evsen L, Doetzlhofer A. Gene Transfer into the Chicken Auditory Organ by In Ovo Microelectroporation. J Vis Exp. 2016;5(110):25-41.

19.Nesbit SC, Van Hoof AG, Le CC, Dearworth Jr JR. Extracellular recording of light responses from optic nerve fibers and the caudal photoreceptor in the crayfish. J Undergrad Neurosci Edu. 2015;14 (2): 29-35.

20.Zhou Z, Luther N, Singh R, Boockvar JA, Souweidane MM, Greenfield JP. Glioblastoma spheroids produce infiltrative gliomas in the rat brainstem. Childs Nerv Syst. 2017;33(3):437-46.

21.Augestad IL, Nyman AKG, Costa AI, Barnett SC, Sandvig A, Håberg AK, et al. Effects of neural stem cell and olfactory ensheathing cell co-transplants on tissue remodelling after transient focal cerebral ischemia in the adult rat. Neurochem Res. 2017;42(6):1599-609.

22.Hewing NJ, Weskamp G, VermaatJ, Farage E, Glomski K, Swendeman S, et al. Intravitreal injection of TIMP3 or the EGFR inhibitor erlotinib offers protection from oxygen-induced retinopathy in mice. Invest Ophthalmol Vis Sci. 2013;54(1):864-70.

23.Nickerson JM, Goodman P, Chrenek MA, Bernal CJ, Berglin L, Redmond TM, et al. Subretinal delivery and electroporation in pigmented and nonpigmented adult mouse eyes. Retin Develop: Springer; 2012. p. 53-69.

24.Johnson CJ, Berglin L, Chrenek MA, Redmond T, BoatrightJH, Nickerson JM. Technical brief: subretinal injection and electroporation into adult mouse eyes. Mol Vis. 2008;14(1):2211-18.

25.Machalińska A, Lubiński W, Kłos P, Kawa M, Baumert B, Penkala K, et al. Sodium iodate selectively injuries the posterior pole of the retina in a dose-dependent manner: morphological and electrophysiological study. Neurochem Res. 2010;35(11):1819-27.

26.Kita M, Negi A, Kawano S, Honda Y, Maegawa S. Measurement of retinal adhesive force in the in vivo rabbit eye .Investigative ophthalmol Vis Sci. 1990;31(4):624-8.

27.Fernandes RAB, Stefanini FR, Falabella P, Koss MJ, Wells T, Diniz B, et al. Development of a new tissue injector for subretinal transplantation of human embryonic stem cell derived retinal pigmented epithelium. Int J Retina Vitreous. 2017;3(1):41.

28. Oner A, Gonen ZB, Sinim N, Cetin M, Ozkul Y. Subretinal adipose tissue-derived mesenchymal stem cell implantation in advanced stage retinitis pigmentosa: a phase I clinical safety study. Stem Cell Res Ther. 2016;7(1):178.

29.Abe T, Yoshida M, Tomita H, Kano T, Sato M, Wada Y, et al. Auto iris pigment epithelial cell transplantation in patients with age-related macular degeneration: short-term results. Tohoku J Exp Med. 2000;191(1):7-20.

30.Verdugo ME, Alling J, Lazar ES, Del Cerro M, Ray J, Aguirre G. Posterior segment approach for subretinal transplantation or injection in the canine model. Cell Transplant. 2001;10(3):317-27.

31.de Smet MD, Lynch JL, Dejneka NS, Keane M, Khan IJ. A subretinal cell delivery method via suprachoroidal access in minipigs: safety and surgical outcomes. Invest Ophthalmol Vis Sci. 2018;59(1):311-20.

32. You YS, Lee CY, Li C, LeeSH, Kim K, Jung H. An arched micro-injector (ARCMI) for innocuous subretinal injection. PloS One. 2014;9(8):e104145.

33.Schwartz SD, Tan G, Hosseini H, Nagiel A. Subretinal transplantation of embryonic stem cellderived retinal pigment epithelium for the treatment of macular degeneration: an assessment at 4 years. Invest Ophthalmol Vis Sci. 2016;57(5):1-9.

34.Xie W, Yan R-T, Ma W, Wang S-Z. Enhanced retinal ganglion cell differentiation by ath 5 and NSCL1 coexpression. Invest Ophthalmol Vis Sci. 2004;45(9):2922-8 . 